\title{
EFFECT OF URSODESOXYCHOLIC ACID UPON THE INTESTINAL ABSORPTION OF RIBOFLA- VIN IN GUINEA PIGS
}

\author{
TSUNEO ARAKAWA, AKIRA KAGAYA AND YAKUMO INABA \\ Department of Pediatrics, School of Medicine, Hirosaki University, \\ Sagara-cho, Hirosaki
}

(Received Appril 18, 1957)

The effect of bile acid, especially ursodesoxycholic acid, upon the intestinal absorption of riboflavin was investigated on guinea pigs.

TABLE I

Effect of Cholic Acid upon Intestinal Absorption of Riboflavin in Guinea Pigs

\begin{tabular}{|c|c|c|c|c|c|c|c|c|c|c|c|}
\hline \multirow{3}{*}{$\begin{array}{l}\text { No. of } \\
\text { intes- } \\
\text { tinal } \\
\text { prepa- } \\
\text { ration }\end{array}$} & \multirow{3}{*}{$\begin{array}{l}\text { Composition of the } \\
\text { solution injected } \\
\text { into the lumen of } \\
\text { the intestinal } \\
\text { preparation }\end{array}$} & \multicolumn{10}{|c|}{ Riboflavin in the intestinal wall $(\gamma / g)$} \\
\hline & & \multicolumn{2}{|c|}{ No. 1} & \multicolumn{2}{|c|}{ No. 2} & \multicolumn{2}{|c|}{ No. 3} & \multicolumn{2}{|c|}{ No. 4} & \multicolumn{2}{|c|}{ No. 5} \\
\hline & & Total & Ester. & Total & Ester. & Total & Ester. & Total & Ester. & Total & Ester. \\
\hline$a$ & $\begin{array}{l}50 \gamma \mathrm{FR}^{a} \text { in } 1.0 \mathrm{ml} \\
\mathrm{H}_{2} \mathrm{O}+0.5 \mathrm{ml} 0.5 \% \\
\text { cholic acid in } N / 50 \\
\mathrm{NaOH}\end{array}$ & 7.20 & 3.39 & 8.25 & 4.27 & 4.42 & 3.09 & 5.98 & 3.80 & 5.42 & 3.21 \\
\hline$b$ & $\begin{array}{l}1.0 \mathrm{ml} \mathrm{H} \mathrm{H}_{2} \mathrm{O}+0.5 \mathrm{ml} \\
0.5 \% \mathrm{cholic} \text { acid in } \\
N / 50 \mathrm{NaOH}\end{array}$ & 3.04 & 2.06 & 2.79 & 2.21 & 3.19 & 2.52 & 2.92 & 2.36 & 2.54 & 2.03 \\
\hline \multicolumn{2}{|c|}{$\begin{array}{l}\text { Riboflavin absorbed in the } \\
\text { intestinal wall } A=a-b\end{array}$} & 4.16 & 1.33 & 5.46 & 2.06 & 1.23 & 0.57 & 3.06 & 1.44 & 2.88 & 1.18 \\
\hline$c$ & $\begin{array}{l}50 \gamma \mathrm{FR} \text { in } 1.0 \mathrm{ml} \\
\mathrm{H}_{2} \mathrm{O}+0.5 \mathrm{ml} \mathrm{N} / 50 \\
\mathrm{NaOH}\end{array}$ & 6.28 & 3.15 & 7.39 & 3.98 & 4.22 & $2.9 ?$ & 4.93 & 3.17 & 5.81 & 3.39 \\
\hline$d$ & $\begin{array}{l}1.0 \mathrm{ml} \mathrm{H}_{2} \mathrm{O}+0.5 \mathrm{ml} \\
N / 50 \mathrm{NaOH}\end{array}$ & 2.93 & 2.00 & 3.27 & 2.49 & 2.95 & 2.37 & 3.10 & 2.48 & 2.90 & 2.24 \\
\hline \multicolumn{2}{|c|}{$\begin{array}{l}\text { Riboflavin absorbed in the } \\
\text { intestinal wall } B=c-d\end{array}$} & 3.35 & 1.15 & 4.12 & 1.29 & 1.27 & 0.53 & 1.83 & 0.69 & 2.91 & 1.19 \\
\hline \multicolumn{2}{|c|}{$\begin{array}{l}\text { Increase or decrease in the } \\
\text { riboflavin absorbed in the } \\
\text { intestinal wall by adding } \\
\text { cholic acid }(\gamma / g)=A-B\end{array}$} & 0.81 & 0.18 & 1.34 & 0.77 & --0.04 & 0.04 & 1. 23 & 0.57 & -0.03 & 0.03 \\
\hline \multicolumn{2}{|c|}{$\begin{array}{l}\text { Percentage increase or dec- } \\
\text { rease in the riboflavin ab- } \\
\text { sorbed in the intestinal } \\
\text { wall by adding cholic acid } \\
=\frac{A-B}{B} \times 100\end{array}$} & 23 & 15 & 32 & 59 & -3 & 7 & 67 & 108 & -1 & 2 \\
\hline
\end{tabular}

The average for $A-B$ in $\gamma / \mathrm{g}:$ total, $0.66 \pm 0.82$; esterified, $0.35 \pm 0.46$.

The average for $\frac{A-B}{B} \times 100$ in $\%$ : total, $23 \pm 31$; esterified $23 \pm 50$.

a Free riboflavin. 


\section{METHODS}

The small intestine was isolated from a guinea pig and four parts of the intestine $(1,2,3$ and 4$)$, in the length of $15 \mathrm{~cm}$ each, were prepared. Each preparation was washed with the Tyrode solution and ligatured at both ends. The solutions, as listed in Tables I-III, were introduced into the lumen of the prepared intestines, followed by incubating in the Tyrode solution at $38^{\circ}$ for 30 minutes with continuous aeration through the solution. The bile acids examined were cholic acid, desoxycholic acid and ursodesoxycholic arid. ${ }^{1}$ The riboflavin content of the intestinal wall of each preparation was estimated with a lumiflavin method (2).

\section{RESULTS AND DISCUSSION}

On the averages for 5 cases (Nos. 1-5) with an addition of cholic acid, the

TABLE II

Effect of Desoxycholic Acid upon Intestinal Absorption of Riboflavin in Guinea Pigs

\begin{tabular}{|c|c|c|c|c|c|c|c|c|c|c|c|}
\hline \multirow{3}{*}{$\begin{array}{l}\text { No. of } \\
\text { intes- } \\
\text { tinal } \\
\text { prepa- } \\
\text { ration }\end{array}$} & \multirow{3}{*}{$\begin{array}{l}\text { Composition of the } \\
\text { solution injected } \\
\text { into the lumen of } \\
\text { the intestinal } \\
\text { preparation }\end{array}$} & \multicolumn{10}{|c|}{ Riboflavin in the intestinal wall. $(\gamma / g)$} \\
\hline & & \multicolumn{2}{|c|}{ No. 6} & \multicolumn{2}{|c|}{ No. 7} & \multicolumn{2}{|c|}{ No. 8} & \multicolumn{2}{|c|}{ No. 9} & \multicolumn{2}{|c|}{ No. 10} \\
\hline & & Total & Ester. & Total & Ester. & Total & Ester. & Total & Ester. & Total & Ester. \\
\hline$a$ & $\begin{array}{l}50 \gamma \mathrm{FR} \text { in } 1.0 \mathrm{ml} \\
\text { of } \mathrm{H}_{2} \mathrm{O}+0.5 \mathrm{ml} \mathrm{of} \\
0.5 \% \text { desoxycholic } \\
\text { acid in } N / 50 \mathrm{NaOH}\end{array}$ & 7.05 & 3.42 & 6.11 & 3.46 & 5.25 & 3.31 & 4.65 & 3.23 & 5.86 & 3.80 \\
\hline$b$ & $\begin{array}{l}1.0 \mathrm{ml} \text { of } \mathrm{H}_{2} \mathrm{O}+0.5 \\
\text { ml of } 0.5 \% \text { desoxy- } \\
\text { cholic acid in } N / 50 \\
\mathrm{NaOH}\end{array}$ & 2.82 & 2.08 & 2. 78 & 1. 67 & 2.58 & 1.90 & 3.07 & 2.54 & 3.22 & 2.73 \\
\hline \multicolumn{2}{|c|}{$\begin{array}{l}\text { Riboflavin absorbed in the } \\
\text { intestinal wall } A=a-b\end{array}$} & 4.23 & 1.34 & 3.33 & 1.79 & 2.67 & 1.41 & 1.58 & 0.69 & 2.64 & 1.07 \\
\hline$c$ & $\begin{array}{l}50 \gamma \mathrm{FR} \text { in } 1.0 \mathrm{ml} \\
\text { of } \mathrm{H}_{2} \mathrm{O}+0.5 \mathrm{ml} \text { of } \\
N / 50 \mathrm{NaOH}\end{array}$ & 6.25 & 3.35 & 5.74 & 3.31 & 4.63 & 2.83 & 4.62 & 3.16 & 4.68 & 3.11 \\
\hline$d$ & $\begin{array}{l}1.0 \mathrm{ml} \text { of } \mathrm{H}_{2} \mathrm{O}+0.5 \\
\mathrm{ml} \text { of } \mathrm{N} / 50 \mathrm{NaOH}\end{array}$ & 2.53 & 1.84 & 2.82 & 2.38 & 2.58 & 2.07 & 2.86 & 2.51 & 3.50 & 2.88 \\
\hline \multicolumn{2}{|c|}{$\begin{array}{l}\text { Riboflavin absorbed in the } \\
\text { intestinal wall } B=c-d\end{array}$} & 3.72 & 1.51 & 2.92 & 0.93 & 2.05 & 0.76 & 1.76 & 0.65 & 1.18 & 0.23 \\
\hline \multicolumn{2}{|c|}{$\begin{array}{l}\text { Increase or decrease in the } \\
\text { riboflavin absorbed in the } \\
\text { intestinal wall by adding } \\
\text { desoxycholic acid } A-B\end{array}$} & 0.51 & -0.17 & 1.41 & 0.86 & 0.62 & 0.65 & -0.16 & 0.04 & 1.46 & 0.84 \\
\hline \multicolumn{2}{|c|}{$\begin{array}{l}\text { Percentage of increase or } \\
\text { decrease in the riboflavin } \\
\text { absorbed in the intestinal } \\
\text { wall by adding desoxycho- } \\
\text { lic acid } \\
\frac{A-B}{B} \times 100\end{array}$} & 13 & -11 & 48 & 92 & 30 & 85 & -9 & 6 & 106 & 365 \\
\hline
\end{tabular}

The average for $A-B$ in $\boldsymbol{\gamma} / \mathrm{g}:$ total, $1.16 \pm 1.19$; esterified, $0.78 \pm 0.37$

The average for $A-B \times 100$ in $\%$ : total, $37 \pm 95$; esterified, $107 \pm 150$.

1 Synthesized by Sato et al. (1).

2 Fiducial limits with a level of significance of 95 per cent 
TABLE III

Effect of Ursodesoxycholic Acid upon Intestinal Absorption of Riboflavin in Guinea Pigs

\begin{tabular}{|c|c|c|c|c|c|c|c|c|c|c|c|}
\hline \multirow{3}{*}{$\begin{array}{l}\text { No. of } \\
\text { intes- } \\
\text { tinal } \\
\text { prepa- } \\
\text { ration }\end{array}$} & \multirow{3}{*}{$\begin{array}{l}\text { Composition of the } \\
\text { solution injected } \\
\text { into the lumen of } \\
\text { the intestinal } \\
\text { preparation }\end{array}$} & \multicolumn{10}{|c|}{ Riboflavin in the intestinal wall $(\gamma / g)$} \\
\hline & & \multicolumn{2}{|c|}{ No. 11} & \multicolumn{2}{|c|}{ No. 12} & \multicolumn{2}{|c|}{ No. 13} & \multicolumn{2}{|c|}{ No. 14} & \multicolumn{2}{|c|}{ No. 15} \\
\hline & & Total & Ester. & Total & Ester. & Total & Ester. & Total & Ester. & Total & Ester. \\
\hline$a$ & $\begin{array}{l}50 \% \mathrm{FR} \text { in } 1.0 \mathrm{ml} \\
\text { of } \mathrm{H}_{2} \mathrm{O}+0.5 \mathrm{ml} \text { of } \\
0.5 \% \text { ursodesoxy } \\
\text { choolic acid in N/50 } \\
\mathrm{NaOH}\end{array}$ & 6.98 & 3.70 & 6.94 & 3.92 & 7.40 & 3.82 & 6.91 & 4.40 & 6.86 & 4.12 \\
\hline$u$ & $\begin{array}{l}1.0 \mathrm{ml} \text { of } \mathrm{H}_{2} \mathrm{O}+0.5 \\
\text { ml of } 0.5 \% \text { ursodes. } \\
\text { oxycholic acid in } \\
N / 50 \mathrm{NaOH}\end{array}$ & 3.23 & 2.60 & 3.49 & 2.60 & 2.61 & 1.77 & 3.11 & 2.18 & 3.25 & 2.53 \\
\hline \multicolumn{2}{|c|}{$\begin{array}{l}\text { Riboflavin absorbed in the } \\
\text { intestinal wall } A=a-b\end{array}$} & 3.75 & 1.10 & 3.45 & 1.32 & 4.79 & 2.05 & 3.80 & 2.20 & 3.61 & 1.59 \\
\hline$c$ & $\begin{array}{l}50 \mathrm{FR} \text { in } 1.0 \mathrm{ml} \\
\text { of } \mathrm{H}_{2} \mathrm{O}+0.5 \mathrm{ml} \text { of } \\
\mathrm{N} / 50 \mathrm{NaOH}\end{array}$ & 6.09 & 3.37 & 5.59 & 3.21 & 5.96 & 2.83 & 5.19 & 3.40 & 6.27 & 3.73 \\
\hline$d$ & $\begin{array}{l}1.0 \mathrm{ml} \text { of } \mathrm{H}_{2} \mathrm{O}+0.5 \\
\mathrm{ml} \text { of } N / 50 \mathrm{NaOH}\end{array}$ & 3.19 & 2.19 & 3.10 & 2.42 & 2.72 & 1.82 & 3.02 & 2.36 & 3.17 & 2.66 \\
\hline \multicolumn{2}{|c|}{$\begin{array}{l}\text { Riboflavin absorbed in the } \\
\text { intestinal wall } B=c-d\end{array}$} & 2.90 & 1.18 & 2.49 & 0.79 & 3.24 & 0.99 & 2.17 & 1.04 & 3.10 & 1.07 \\
\hline \multicolumn{2}{|c|}{$\begin{array}{l}\text { Increase or decrease in the } \\
\text { riboflavin absorbed in the } \\
\text { intestinal wall by adding } \\
\text { ursodesoxycholic acid } A-B\end{array}$} & 0.85 & -0.08 & 0.96 & 0.53 & 1.55 & 1.06 & 1.63 & 1.18 & 0.50 & 0.52 \\
\hline \multicolumn{2}{|c|}{$\begin{array}{l}\text { Percentage of increase or } \\
\text { decrease in the riboflavin } \\
\text { absorbed in the intestinal } \\
\text { wall by adding ursodesoxy } \\
\text { cholic acid } \\
\frac{A-B}{B} \times 100\end{array}$} & 29 & -6 & 38 & 67 & 47 & 107 & 75 & 113 & 16 & 48 \\
\hline
\end{tabular}

The average for $A-B$ in $\gamma / g$ : total, $1.16 \pm 0.84$; esterified, $0.82 \pm 0.56$.

The average for $\frac{A-B}{B} \times 100$ in $\%:$ total, $41 \pm 22$; esterified, $65 \pm 55$.

intestinal absorption of total riboflavin was increased by $23 \pm 31^{2} \%$, and that of esterified riboflavin was increased by $23 \pm 50 \%$ (cf. Table I).

On the average for 5 cases (Nos. 6-10) with an addition of desoxycholic acid, the intestinal absorption of the total riboflavin was increased by $37 \pm 95 \%$, and that of the esterified riboflavin was increased by $107 \pm 150 \%$ (cf. Table II).

On the averages for 5 cases (Nos. 11-15) with an addition of ursodesoxycholic acid, the intestinal absorption of total riboflavin was increased by $41 \pm$ $22 \%$, and that of esterified riboflavin was increased by $65 \pm 55 \%$.

These figures showed that a significant increase in the intestinal absorption and riboflavin phosphorylation in guinea pigs were found only in the cases with ursodesoxycholic acid, but not in those with cholic or desoxycholic acid.

Recently Onishi (3), using a perfusion technique in dogs, demonstrated a marked increase in the intestinal absorption and riboflavin phosphorylation in the presence of ursodesoxycholic acid. 


\section{SUMMARY}

The intestinal absorption and riboflavin phosphorylation was shown to be accelerated significantly by ursodesoxycholic acid in guinea pigs.

\section{ACKNOWLEDGEMENT}

The authors wish to thank Professor Tayei Shimizu, the President of Okayama University, for his encouragement.

\section{REFERENCES}

1. Sato, T., Kanazawa, T., Shimazaki, A., and Hoshino, T., Proc. Japan Acad. 30. 391 (1954).

2. Kagaya, A., Vitamins 6, 777 (1953).

3. Onishi, N., ibid. 11, 479 (1956). 